\title{
6.8
}

\section{London: government and politics in the boroughs}

Within London the 32 London boroughs undertake most local services provision and planning, and play a major role in shaping the capital's evolution. Tony Travers looks at how well they fulfil their roles.

\section{What does democracy require of London's borough councils?}

$\downarrow$ Elected politicians should normally maintain full executive control of local government and the public services that councils are required or empowered to deliver. In the London system, there are two tiers of sub-national government, the 32 boroughs (plus the City of London) and the Greater London Authority (the GLA, consisting of a mayor and Assembly; see Chapter 6.7 ). The latter has no supervisory responsibility over the former.

$\downarrow$ Boroughs should represent local and neighbourhood interests whereas the GLA represents London-wide ones. The second-tier authorities should be the focus of local democracy in the delivery of municipal services and leadership.

$\downarrow$ Individually and collectively, London's councils should not only deliver publicly accountable services but also, in effect, act as a democratic counter-balance to the city-wide power of the mayor.

$\downarrow$ Councils should have accountable, effective and responsive leadership, with an understanding of the needs of all their citizens and acting in ways responsive to public opinion.

$\downarrow$ In addition to their representative role on behalf of their constituents, the nonexecutive members of the London borough councils should undertake oversight and scrutiny functions so as to provide strengthened performance and accountability.

$\downarrow$ London's borough government should be consistently and predictably funded in such a way as to provide a link between raising of resources and their use, while also being sufficient to deliver legislatively required public services.

$\downarrow$ London councils should be a stable part of UK local government, with some quasiconstitutional protection against ad hoc, inconsistent and/or partisan interventions from other tiers of government. 
The London boroughs represent a long-established and accessible element in the government of a very large mega-city. With an average population of 275,000 , London boroughs are substantial municipalities by international standards. Two of the outer boroughs are forecast to have populations in excess of 400,000 by the early 2020 s. The scale of London's 8.9 million population makes it hard to envisage a system of government that did not include a local-scale tier capable of representing neighbourhood and community interests. The boroughs (and the still surviving City of London) are relatively powerful units of sub-national government in London. Taken together, their total budget is broadly twice the spending of the top-tier Greater London Authority. So the capital's arrangement can be characterised as a bottom-heavy, two-tier system.

Each of the 32 councils is generally led by a cabinet, consisting of a sub-group of the elected members chosen from either the majority party, or a coalition/combination of two minority ones. In four cases (Hackney, Lewisham, Newham and Tower Hamlets) there is a separately elected executive mayor who holds executive power.

In common with local authorities throughout England, the London boroughs' responsibilities for service delivery have been much reduced by the growth of micro-local agencies (like schools), but they have become far more active as local economic development institutions. Local government now has only residual responsibilities over education, for example, where once this was their biggest spending function. Borough councils in the capital each have between 45 and 70 councillors, with significant disparities in the numbers of registered voters (and, separately, total population) per elected member. Councillors stand for election every four years (when all seats are up for election). There have been 15 of these elections since the boroughs were created in 1964.

\section{Recent developments}

As with local government elsewhere in England, London borough elections use the firstpast-the-post ('plurality') voting system (see Chapter 2.1). Figure 1 shows that the system greatly advantaged Labour in both 2018 and 2014, with the party winning a 'leader's bonus' of an extra 18\% of seats compared to its vote share in 2018 (down a little on $21 \%$ in 2014). The Conservatives' vote share across London rose $2.4 \%$, but their numbers of councillors elected dropped by nearly one in six. UKIP had one in eleven votes in 2014 but lost almost all of them in 2018. The Liberal Democrats' vote share improved a good deal in south-west London, but only somewhat across the capital as a whole. The Greens' vote share dropped back, but they gained a handful more seats. The 'other' councillors elected were for local residents' groups. Overall the deviation from proportionality (DV) score (see Chapter 2.1) improved a little to a still high 17.6 \% (compared with $20.7 \%$ in 2014).

In terms of whole councils changing hands, Figure 2 shows that Labour gained one more to control 21 boroughs (adding Tower Hamlets), but failed to topple Tory control in their innerurban strongholds of Westminster and Wandsworth. The Conservatives controlled seven (down by two net). The Liberal Democrats won three councils (an increase of two), with one council in no overall control. (The City of London largely eschews party politics, and holds its elections every four years on a different cycle. The most recent occurred in March 2017, with one of the major national parties [Labour] gaining an unprecedented five seats.) 
Figure 1: The outcomes of the 2018 and 2014 London borough elections

\begin{tabular}{|l|r|r|r|r|r|r|}
\hline & \multicolumn{2}{|l|}{$\mathbf{2 0 1 8}$} & \multicolumn{2}{|c|}{$\mathbf{2 0 1 4}$} \\
\hline Party & votes $\%$ & seats & seats\% & votes\% & seats & seats\% \\
\hline Labour & 43.9 & 1,128 & 61.5 & 37.6 & 1,061 & 58.3 \\
\hline Conservative & 28.8 & 508 & 27.7 & 26.4 & 600 & 33.0 \\
\hline Liberal Democrats & 13 & 152 & 8.3 & 10.6 & 118 & 6.5 \\
\hline Green & 8.6 & 11 & 0.6 & 9.8 & 4 & 0.2 \\
\hline UKIP & 0.9 & 0 & 0.0 & 9.5 & 9 & 0.5 \\
\hline Others & 4.8 & 34 & 1.9 & 6.1 & 27 & 1.5 \\
\hline Total & 100 & $\mathbf{1 , 8 3 3}$ & 100 & 100 & $\mathbf{1 , 8 1 9}$ & 100 \\
\hline
\end{tabular}

Source: Re-computed from Wikipedia, 2018

There were also four mayoral elections, in the Labour boroughs of Hackney, Lewisham, Tower Hamlets and Newham, all of which the party easily retained. In Newham the 23year leadership of Sir Robin Wales (16 of them as elected mayor) was ended when an election amongst Labour Party members and affiliates (attracting nearly 1,400 votes) chose Rokhsana Fiaz instead of him as their candidate. She duly won over $73 \%$ of the first preference votes in May 2018, becoming the first directly elected female mayor for any London borough. She has promised to hold a referendum on whether to keep a directly elected mayor or go back to a council with 'party leader' model.

Figure 2: Political control of London boroughs after the 2018 elections

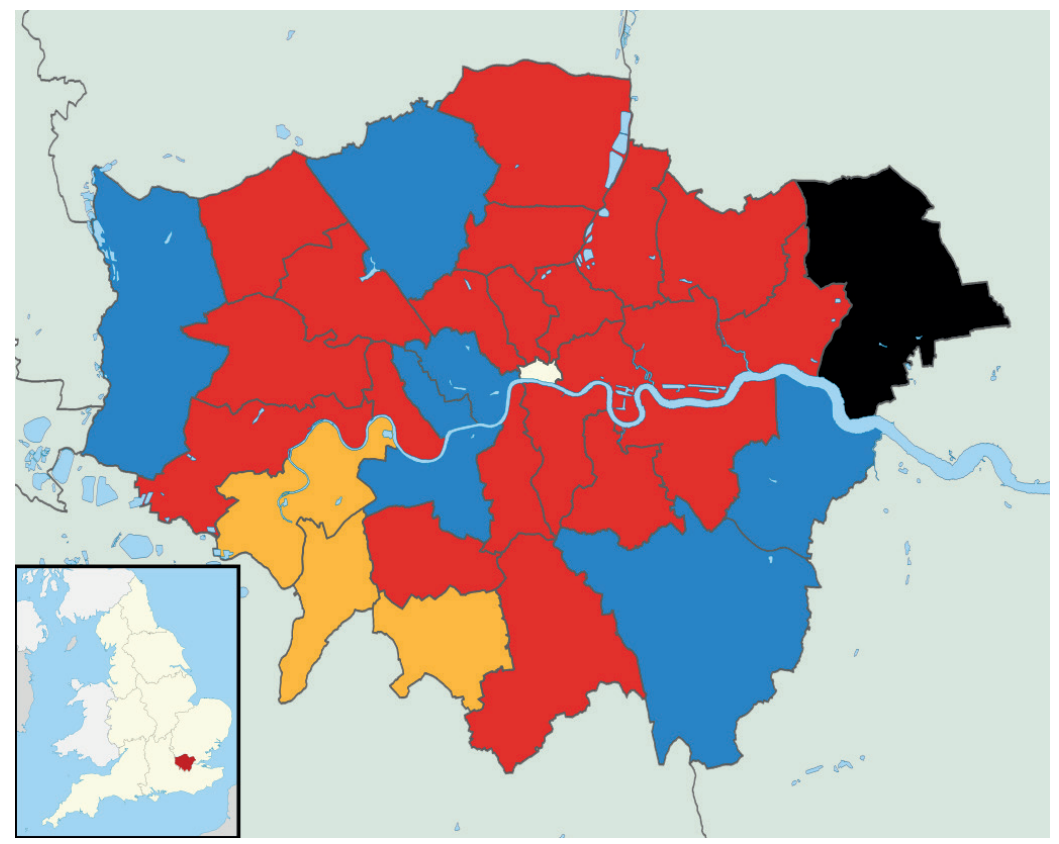

Source: Wikipedia 2018, created using Ordnance Survey maps

Notes: Black indicates no overall control 
In 2018, the turnout was estimated at 36\% for all the English local elections that took place. In years unaffected by general elections, the highest-ever turnout was $48 \%$ in 1990 and the lowest was $32 \%$ in 2002 . Turnout in the 2014 borough contests averaged $39 \%$. (It was $62 \%$ in 2010, when the borough elections were held on the same day as the general election.)

In late 2014, after complaints of election fraud and corruption in Tower Hamlets' administration, the central government appointed commissioners to take over its running, to support the council improvement and to ensure transparent and open governance. In particular, the commissioners assumed direct responsibility for the borough's grant-giving. In 2015, the May 2014 election of Tower Hamlets' executive mayor Lutfur Rahman, who drew heavily on support from the Bangladeshi community, was declared null and void by the Election Court because of electoral fraud within the terms of the Representation of the People Act, 1983. Rahman was disbarred from public office until 2021. Some critics argued that the episode highlighted systemic weaknesses. However, subsequently, a new Labour mayor was elected and the commissioners were stood down. In 2018, the Labour mayor was re-elected and Tower Hamlets returned to majority Labour control.

In June 2017, a disastrous fire occurred at Grenfell Tower in Kensington and Chelsea borough, killing 72 people, with at least 223 people rescued. The consequences of the fire and a woeful aftermath in terms of meeting survivors' needs included the (forced) resignation of the borough's chief executive, followed later by the Conservative council leader and deputy leader. In the immediate aftermath of the disaster, a joint ('Gold Command') arrangement of other borough chief executives and officers assumed control of recovery and administration. The government announced that a task force (with advisory not executive powers) would be appointed to assist the longer-term recovery from the fire and its impacts. Kensington and Chelsea's new Tory leader admitted that trust in the council had been seriously damaged by the incident and the council's subsequent response. A major public inquiry began in mid-2018 and its findings are certain to have far-reaching consequences for London governance, building regulation and councils' relations with their tenants. Nevertheless, the borough was retained by the Conservatives in the 2018 election. 


\section{Strengths, Weaknesses, Opportunities and Threats (SWOT) analysis}

\section{Current strengths}

In many boroughs there is effective competition between two or more parties, with the real chance of a change of control at forthcoming elections. The Conservatives, Labour and the Liberal Democrats are active in every borough, while there has been some growth in minor parties in recent decades. However, in 2018 , only $9.5 \%$ of votes cast in the borough elections went to parties other than the big three (down from over $26 \%$ in 2014). This resulted in 'others' winning only $2.5 \%$ of seats.
Turnouts at 38-39\% have been around 5-6\% higher than at the turn of the century, but below the levels of the politically charged 1980s and early 1990s. Political controversy seems to drive up turnout.

Stability is a key attribute of the London boroughs. Because they have survived with virtually the same boundaries and many of the same service responsibilities for 52 years, they are now the oldest municipalities in the UK. Virtually all other public providers have been reorganised more frequently. Despite their lack of any formal constitutional protection, the London boroughs have proved resilient within a UK government system which is subject to regular administrative 'churn'. The City of London, an exception to virtually all rules, is almost a thousand years old.

\section{Current weaknesses}

Because of distortions produced by plurality rule voting (see Chapter 2.1) there is far less democratic competition in some boroughs than others. In Lewisham, Newham and Barking and Dagenham Labour holds all the seats on the council - although Labour also gained $77 \%$ of votes in Barking. In Islington the majority party holds all but one and in Lambeth Labour won 54\% of votes but holds nearly $91 \%$ of council seats: the five opposition councillors left cannot cover everything. The number of minority party councillors on a number of councils is below $10 \%$ of the total. The make-up of the electorate and ward boundaries often compound the problems. There are also other boroughs, such as Tory-controlled Westminster and Kensington and Chelsea, where there has never been a change of control, though there is a sizeable opposition in both.

Turnout levels, which are historically around $36-39 \%$, are just on a par with other UK local elections, and low by international standards. In 2018 turnout across Kensington and Chelsea rose to 39\% but was as low as 30\% in Barking and Dagenham, though Richmond achieved 51\%.

The City of London's democratic position is anomalous and has been for decades. Its franchise includes business votes, a characteristic that was unique in modern sub-national government until business improvement districts came into existence in the 2000s. The latter are business-led, but have access to non-domestic rates as a revenue source. In addition, many larger London businesses are now required to pay a supplementary local rate to fund the Crossrail project. 


\section{Current strengths}

Local responsiveness is perhaps the single most important virtue of London boroughs and their councillors. There are over 1,800 councillors in London (compared to $73 \mathrm{MPs}$ and to 25 London Assembly members, only 14 with constituency roles). So London borough wards cover an area or neighbourhood that is small enough to allow easy access to elected representatives. In a city as large as London (1,572 sq km), residents have a need for both local and citywide voice. Borough councillors make locally sensitive representation possible.

London is by far the most diverse part of the UK. The most recent census of the city's councillors (in 2013) suggested nearly $16 \%$ were from black and minority ethnic communities, and this share probably increased in 2014 and 2018 - in line with the 2017 general election when just over $16 \%$ of London's MPs came from BME backgrounds. Only a third of London councillors are female.

The boroughs are capable of representing themselves and their democratic position within UK government in negotiations with the mayor and Whitehall. A jointly funded representative body, London Councils, acts both to safeguard borough interests during the passage of legislation and in lobbying for greater devolution, as well as being the collective voice for boroughs in relation to national and city-wide government and to other institutions.

\section{Current weaknesses}

The processes that political parties use to choose candidates are not easy for the wider public to understand, though this issue is not unique to London. Parties are private organisations which have their own processes for selecting candidates for all types of election. The closed nature of party selections may from time to time encourage 'entryism'. Here a sub-set of party members within a party become able to choose candidates by surviving long meetings, procedural struggles and other ways of operating that discourage participation by the wider local membership.

There have been examples of electoral fraud in a number of British councils in recent years including, notoriously, in Tower Hamlets. Although London elections are generally well-managed and clean, there have been accusations of malpractice, though there have been very few examples of proven fraud. Since the Tower Hamlets case greater efforts have been made to monitor electoral registers, postal voting and (with police assistance) polling stations.

The small size and multiplicity of London boroughs are criticised from time to time. Thirty-two boroughs seems a large number of authorities for a relatively small geographical area. Some critics have suggested a move to 14 (the number of Assembly constituencies) or even five 'super boroughs'. From a democratic point of view, reducing the number of boroughs would inevitably reduce the number of elected representatives, and cut the possibility of access by the public. Five boroughs would mean each having an average population of 1.8 million, almost twice the size of Birmingham City Council. If boroughs were that large, some form of 'parish' or 'community' council would doubtless be required, thus creating three tiers of sub-national government within London. 


\section{Current strengths Current weaknesses}

(Some shire areas already have county, district and parish councillors, which can be seen as complex.) In democratic terms, any reform of London borough government would need to take access and local accountability into account.

Since the abolition of the Audit Commission, there have been no objective councilwide assessments of London boroughs' performance. But there has been little evidence to suggest that London boroughs are disproportionately susceptible to management, financial or service failure. Apart from the cases of Tower Hamlets and Kensington and Chelsea discussed above, both one-party dominated for long periods, there have been no examples of significant difficulties affecting individual councils. Given the scale of revenue expenditure cuts demanded of many London boroughs since 2010 (see 'Weaknesses'), their performance can be seen as remarkably good in the circumstances.
Tax-raising by the London boroughs has been centrally constrained since rate capping started in the mid-1980s. From 2010 onwards a number of boroughs have had their revenue spending reduced by between $35 \%$ and $45 \%$ in real terms - a far greater cut than almost all other parts of the public sector. Such sharp cutbacks required boroughs to protect some services, such as social care, while allowing others to take even deeper cuts. Official statistics show central administration, roads and planning have faced reductions of $50 \%$ or more over seven years. The National Audit Office reported in March 2018 on the financial sustainability of English local authorities as a whole, explaining that the scale of change is unprecedented. Government plans show further reductions in non-social care spending at least till 2020. It is hard to see how London boroughs' core capacity cannot be affected by reductions on such a scale.

London's boroughs are stable and effective. Despite very large reductions in centrally set funding in recent years, they have been able to continue to deliver effective services and to regenerate former industrial parts of the city. Public satisfaction scores are generally high. Managing such a massive and complex city is a daily challenge, suggesting that this is one of the better-functioning parts of UK government. Stability has allowed politicians to concentrate on service delivery and regeneration. 


\section{Future opportunities}

The boroughs and the mayor have been jointly negotiating with central government over a further package to devolve powers over skills, employment, criminal justice, housing and health to London. The sense that devolution is a 'process not an event' has created dynamism which was reflected in the London Finance Commission report of January 2017, which argued for fiscal devolution to the boroughs and the mayor.

As the primary planning authorities for the capital, the boroughs have the chance to reduce any short-term impact of Brexit by adjusting their policies to accommodate any shocks that emerge as the UK leaves the EU. More generally, London councils have significant freedom to use planning and regeneration policies to make good the lack of central government funding for investment.

Housing supply is linked to the planning system. Given co-operation involving the mayor and Whitehall, it would be possible to increase the numbers of both affordable and total homes available in London. There is growing central government pressure on councils, land owners and the development industry to increase housing supply. The mayor seeks significant additional 'genuinely affordable' housing. More than any other part of government, the boroughs could create the conditions needed to deliver a rising number of new homes, though such an outcome would require additional borrowing freedoms and greater use of resources created by selling of social housing.

\section{Future threats}

Brexit is a potential threat to the economic development and stability of a number of London boroughs which have in recent years had to harness major projects in order to pay for new local facilities and services. Any abrupt, 'cliff-edge' departure from the EU might adversely affect the tax base of London authorities, especially if and when more taxation powers were to be devolved.

Any recession, whether or not linked to Brexit, could also threaten the boroughs' capacity to deliver the large numbers of new homes needed. The softening of the London property market during 2016-18 changed the economics of many boroughs' regeneration plans.

The fallout from the Grenfell Tower disaster has inevitably included a need for many London councils to spend substantial amounts of money on improving the safety of their high-rise housing blocks. How far central government will assist in funding of these upgrades still remains somewhat unclear. Boroughs affected face shortand longer-term costs that may run into billions of pounds. There is a risk to the availability of social housing and also to the maintenance of buildings other than those affected by post-Grenfell requirements for improvements. 


\section{Future opportunities}

The boroughs can assist the mayor with the delivery of the planned Crossrail 2 transLondon railway. It will require significant amounts of development on sites within a number of boroughs from Enfield and Waltham Forest, across inner and central London, to Sutton and Kingston. Again, the creative use of the planning system will be essential to both tiers of government if they are to generate resources for improved services.

\section{Future threats}

There is always a risk that the government will initiate a reorganisation of the boroughs as a solution to a problem - such as loss of capacity due to revenue spending reductions; or to respond to failings revealed by the Grenfell Tower public inquiry. All local government in the UK is almost permanently under threat of some potential reorganisation.

\section{How the boroughs work and what they do}

Since their creation in 1965 to today, the London boroughs have survived (while the former Greater London Council was abolished by the Thatcher government in 1986), partly because their service responsibilities matter to local residents, even though they have altered significantly over time. The boroughs run social care, environmental services, most roads, public health, part of social housing, some services and oversight for local schools, some special needs transport, waste disposal and the administration of elections. Council leaderships (generally a mayor or cabinet) make policy which is subject to voting and scrutiny by the whole council. In all but one borough there is a majority administration of one party (see Figure 1). Service delivery is the responsibility of non-political professional officers who are appointed by the council.

\section{Two-tier government}

For resident Londoners and businesses, the borough is the unit of government responsible for most local services. The mayor of London and the London Assembly have quite separate responsibilities. There is some overlap: boroughs must fit their local plans within the mayor's overall London Plan, while the mayor is responsible for allocating resources to support affordable housing and can lead policy but does not have a delivery role. The boroughs, on the other hand, work in partnership with City Hall to deliver homes. The mayor's agency, Transport for London, allocates some transport funding to boroughs.

It is relatively easy for the public to understand the differences between the boroughs' responsibilities and those of the mayor. There is probably greater confusion amongst citizens about how the boroughs' responsibilities for social care link to NHS health care, supervised by central government. Failings or deficiencies in the joined-up care of older people can easily lead to finger-pointing between central and local government, as across the rest of England.

In the 18 years since London-wide government was restored, the boroughs have come to accept the Greater London Authority, particularly the office of mayor, as a legitimate 
expression of metropolitan democratic needs. There is no borough-initiated campaign to reform the GLA, though there have been concerns expressed by some borough leaderships about the London Assembly. From time to time, individual boroughs will disagree with the mayor of London about issues such as planning policy or housebuilding. But there is an acceptance that there are two legitimate spheres of sub-national government within London, which will at times disagree, for good democratic reasons.

The capacity of each tier of London government to represent different interests: 'local' and 'metropolitan' is, in effect, part of a de facto constitutional settlement for the capital that balances citizens' own different needs. Despite the lack of a formal UK constitution or a London city charter to mediate between the two tiers of the capital's government, relations are overwhelmingly managed effectively.

\section{Financial dependency and budgets}

In common with other UK local authorities, the boroughs are required to produce a balanced revenue (that is, day-to-day) budget each year. Only capital expenditure projects can be funded by borrowing, and only so long as it is consistent with an official 'prudential code'.

Figure 3 shows the biggest services in London borough government (although over £6bn of the education amount shown is forwarded directly to schools, with councils mainly shaping the capital spending). The large bulk of the monies that councils directly control is spent on social care for the elderly, ill and children, and on housing, local roads and transport, plus planning/regulation services.

Figure 3: Total expenditure across services (in $£$ billions) by the 32 London boroughs in 2016-17)

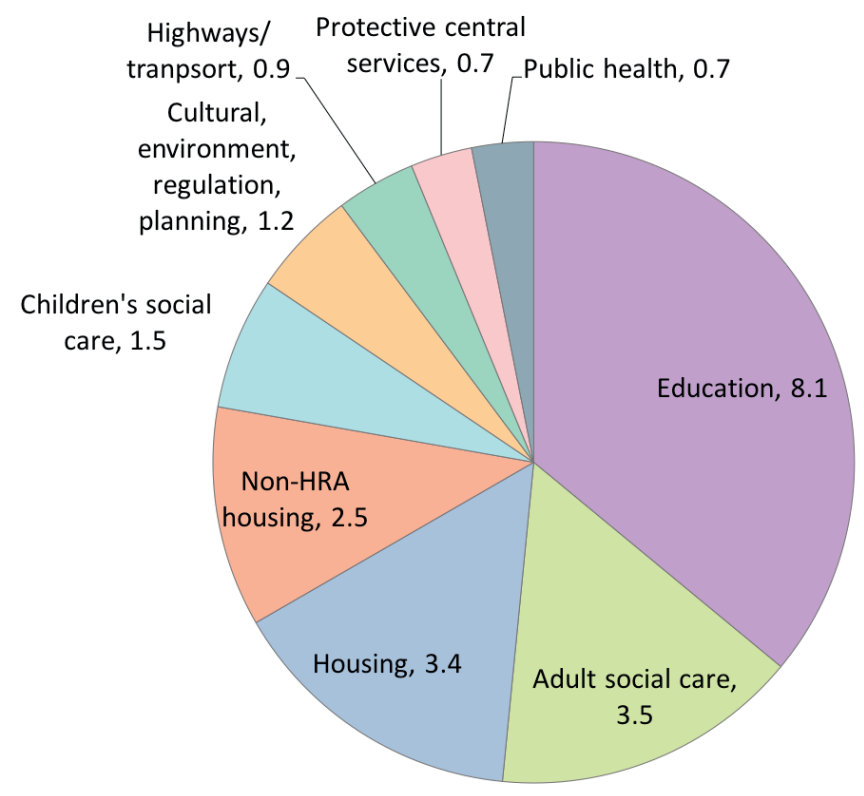

Source: Re-computed from London Councils

Notes: All numbers are in $€$ billions and sum across revenue and capital spending. HRA stands for Housing Revenue Account, roughly housing in local government ownership. 
In terms of the income to cover this spending, over four-fifths of the boroughs' revenue expenditure is funded by government grants from Whitehall or re-distributed business rates (which are still largely centrally controlled). Less than $20 \%$ of revenue spending is funded by the local, property-based, 'council tax'. The latter is effectively capped at a $6 \%$ increase per annum for London councils (until 2018 this was 2\%). To raise any more than this a council would have to propose and then win a local referendum. However, since 2015 the two Conservative governments have encouraged centrally determined increases in council tax to pay for additional social care expenditure. (The government had plans to allow councils to retain $100 \%$ of their non-domestic property tax income from 2020 , though the result of the 2017 general election appears to have reduced the chances of this reform taking place.) Capital expenditure represents just under a quarter of all London boroughs' expenditure and is also partly grant-funded, though to a significantly lesser extent than revenue spending.

\section{Conclusions}

The variegated nature of London's population means that the London boroughs reflect multiple differences that go beyond those related purely to a geographical area. Many groups of ethnic and other minority citizens are often concentrated within small numbers of boroughs. Looking ahead, a greater capacity for councillors to be representative of the many different communities represented in London is a decent goal. Expanding opportunities for neighbourhood involvement in local policy-making would be another. However, there are inevitably clouds in the broadly benign picture for the boroughs. London remains an unequal city, and the centralised nature of UK government means the boroughs and the mayor do not, even jointly, control many of the resources and powers necessary to deliver radical change. Occasionally events occur which are seen, rightly or wrongly, as systemic in their implications. The widespread riots in 2011 were of this kind, as was the 2017 Grenfell Tower disaster. In a city as large and complex as London there is always the risk that an event will occur which will be interpreted as being totemic of broader governmental failure - a risk that London councils are now increasingly mindful of.

Tony Travers is Professor in Practice in the Department of Government at the LSE and Director of LSE London. He is the author of London's Boroughs at 50 (London: Biteback). 